\title{
The Berlin School and Its Global Contexts: A Transnational Art Cinema. Edited by Marco Abel and Jaimey Fisher.
}

\author{
Detroit: Wayne State University Press, 2018. 364 pp.
}

\section{György Kalmár}

Institute of English and American Studies, Faculty of Humanities, University of Debrecen, $\mathrm{H}-4032$

Debrecen, Egyetem tér 1, Hungary; kalmar.gyorgy@arts.unideb.hu

The Berlin School and Its Global Contexts: A Transnational Art Cinema endeavors to redefine the importance of the Berlin School in the context of contemporary international art cinema. The editors' co-authored introduction and the fifteen articles, written by a group of international (but predominantly German) scholars, set out to expand the cinematic contexts in which the school's general significance and specific artistic qualities are to be understood. As such, it is a logical, necessary, and timely addition to previous scholarship on the Berlin School, and an undoubtedly significant contribution to both German film studies and world cinema in general.

The two editors, Abel and Fisher, were the scholars to call international critical attention to contemporary German filmmaking and to promote the possibility of regarding a certain group of directors as the "Berlin School", which would include such better and lesser-known figures as Christian Petzold, Maren Ade, Thomas Arslan, Angela Schanelec, Jessica Hauser, Christoph Hochhäusler, Ulrich Köhler, Benjamin Heisenberg, and Valeska Grisebach. Abel's The Counter-Cinema of the Berlin School (Camden House, 2013) and Fisher's monograph about the movement's most critically acclaimed (and popular) director, Christian Petzold (University of Illinois Press, 2013), were insightful, theoretically ambitious enterprises, which called attention to trends in post-wall German cinema that can be clearly distinguished from the artistic qualities of the New German Cinema of the 1970s, and thus may constitute a new chapter in German film history. They defined the films of Petzold and the others listed above through such concepts as counter-cinema, political cinema, reconfigurations of genre cinema, or auteur cinema, while pointing out their distinctive form of realism and engagement with social and political issues. 
As the anthology's informative introduction also clarifies, the origins of the Berlin School can be traced back to the 1990s when Petzold, Arslan and Schanelec (who are now seen as the school's first generation) studied at the German Film and Television Academy in Berlin. The label "Berlin School" was coined in the early 2000s by German film scholars, at a time when these directors' films started showing more and more artistic (and perhaps also intellectual and political) similarities. Whether this degree of "artistic and intellectual consistency" (p. 2) truly legitimizes branding the above listed directors as "The Berlin School", as the editors openly admit, is widely debated. Neither the editors in the Introduction of the book, nor I would like to drag forth the age-old debates and eternal paradoxes of "What's in a name?", which once perplexed a particular young female Capulet, yet as any marketing expert (and any attentive reader of Shakespeare) surely knows, names, brands, labels, signatures and monikers are far from being purely descriptive in function: they raise curiosity, channel desire, and act as performative trend-setters in our systems of power/knowledge(/money/fame). Though the long list of filmmakers associated with the Berlin School did not attend the same film schools, do not have a recognizable, shared intellectual heritage, and have often voiced concerns about being enlisted under this one label, the terminology used in the book seems intellectually productive, and may thus justify the labelling. After all, most of these films do share several well-definable aesthetic qualities, such as favoring "long takes, long shots, clinically precise framing, a certain deliberateness of pacing, sparse use of non-diegetic music, poetic use of diegetic sound, and, frequently, the reliance on unknown or even non-professional actors who appear to be chosen for who they 'are' rather than for whom they could be" (p. 5).

The most significant contribution of the book to the understanding of the Berlin School, perhaps somewhat ironically, is precisely that it leaves behind the above cited debates about the labelling and questionable school-like qualities of this group of filmmakers (without actually solving them), focusing instead on the immensely more fruitful issues of the films' and filmmakers' affiliations with global art cinema. This aspiration is partly due to the influence of Rosalind Galt and Karl Schoonover, who propagated and theorized the term "global art cinema" in their seminal Global Art Cinema: New Theories and Histories (Oxford University Press, 2010) and infused film studies with a whole set of productive new perspectives. While Abel and Fisher's previous books (as well as the earlier German articles that they built on) predominantly regarded the Berlin School as a German cultural phenomenon, and explored it in the context of German film history, the goal of The Berlin School and Its Global Contexts is to explore the school's "global origins and aftereffects" (p. 1) in order to transcend the admittedly narrow (and somewhat anachronistic) focus of national cinema history and open up the debate to the broader scholarly concerns 
and artistic contexts of twenty-first century global art cinema. As the editors point out, this approach does not only offer a chance to refresh the apparatus of scholarly approaches to the Berlin School, thereby understanding it in more complexity in contemporary screen cultures, but also allows to comprehend the functioning of national (film) cultures within the context of world cinema and global visual culture. Herein lies the double orientation and twofold intellectual profitability of the project, as it may simultaneously break up and enrich the proverbially insular German studies and develop our understanding of world cinema cultures through the infusion of in-depth knowledge about specific national (film) cultures.

The Introduction of the book systematically outlines all these issues, offers a comprehensive context for the fifteen articles that follow, thus serving as a cohesive frame of reference for both the later articles and the reader. A further factor of the book's coherence is due to the fact that the individual articles tend to follow the same pattern, the method of comparing films from the Berlin School with other films or trends in global art cinema. This generally shared method may bring a sense of cohesion to the anthology, yet, from the point of view of global art cinema it may appear uncomfortably close to the approach of comparative literature, a discipline with nineteenth century origins that has been a dominant and popular academic approach in Germany (especially in Berlin). This affinity may be regarded as a slight theoretical problem lurking around some of the texts, as the Eurocentric assumptions of the discipline of comparative literature are clearly at odds with the theoretical frameworks of global art cinema studies. This becomes an issue when we notice the circular (self - other - self; European - non-European - European) journeys of some of the articles, or when we consider the number of German contributors to the volume. Indeed, we may wonder, for example, how these ties of the Berlin School with global art cinema are received by practitioners and researchers in countries with rich film cultures such as Iran, Turkey or South Korea.

The individual articles take the Introduction's initial conceptual framework in all sorts of directions. Though they are written by scholars from first world cultural centers and often share methodological considerations, their basic interests, choices of films, approaches, theoretical frameworks, and analytical methods vary considerably. The global filmmakers in the comparative articles include the American Derek Cianfrance and Kelly Reichardt, the Romanian Corneliu Porumboiu, the Turkish Nuri Bilge Ceylan, the Iranian Abbas Kiarostami, the British Steve McQueen, the Taiwanese Hou Hsiao-Hsien, the Belgian Dardennes brothers, and the Hungarian Béla Tarr, but there are references to New Austrian Cinema and New Argentinian Cinema, as well as to such trends as slow cinema, auteur cinema, or new feminist cinema. One cause of slight dissatisfaction for the reader may stem from the fact that none of the chapters gives a detailed exploration to the most recent, best-known, and 
critically acclaimed films of the Berlin School, such as Ade's Toni Erdmann (2016) or Petzold's Phoenix (2014).

The approaches and theoretical frameworks applied are as colorful as the international contexts they evoke. We find studies of historical influence and genealogy (the chapters by Inga Pollmann, Brad Prager, and Michael Sicinski); feminist analyses of female directors informed by women's cinema (Hester Baer's piece); studies focusing on questions of genre (Lisa Haegele's writing), and issues of national (film) cultures (Robert Dassanowsky's and Gerd Gemünden's articles); explorations of politics and aesthetics, and their interconnections (contributions by Ira Jaffe, Alice Bardan, Inga Pollmann, Lutz Koepnick, Chris Homewood, Brad Prager, and Jaimey Fisher); comparative analyses of stylistic strategies between geographically and culturally distant filmmakers (the articles of Will Fech, Alice Bardan, Roger Cook, Lutz Koepnick, and Gerd Gemünden); and even an essay at the end of the book that interprets films from a philosophical perspective (by Roland Végső).

As the above lists indicate, The Berlin School and Its Global Contexts effectively connects the Berlin School with various important trends in global art cinema, thereby fulfilling its main goal. Despite its minor imperfections (some of which may be traced back to the mundane practical problems besetting edited volumes), it is an illuminating and substantial contribution to the study of both post-wall German filmmaking and contemporary global art cinema. 